\title{
Chinese sea snake (Laticauda semifasciata) misidentified as slender-necked sea snake in previous published account in Korea
}

\author{
II-Hun Kim ${ }^{1,2}$, Jaejin Park', Robert H. Kaplan ${ }^{3}$, Jong-Nam Lee ${ }^{4}$ and Daesik Park ${ }^{5^{*}}$
}

\begin{abstract}
Recent ocean warming near the Korean peninsula and our lack of knowledge of an important vertebrate group, the sea snakes, encouraged us to clarify this part of Korea's regional fauna. We re-examined photographs that had been used to report the slender-necked sea snake (Hydrophis melanocephalus) in 1995. We discovered it was misidentified. To determine the correct identity of the sea snake, we studied 13 original photographs taken at the collecting site in Sooyoung Bay, Busan-si, in 1995 and determined the snake to be Laticauda semifasciata based on enlarged ventral scales, definitive for Laticaudinae sea snakes, and internasal scales, pale blue body color, divided rostral scale, and evident " $V$ "-shaped stripes on the body trunk, definitive for $L$. semifasciata. Therefore, the snake caught 30 years ago in Korean waters should be considered the first record of a Laticaudinae sea snake in Korean waters. L. semifasciata is listed as near threatened setting the stage for urgently needed studies of sea snakes in Korea and supporting those currently underway.
\end{abstract}

Keywords: Korea, Sea snake, Hydrophiinae, Laticaudinae, Laticauda semifasciata

\section{Introduction}

Sea snakes mainly inhabit Atlantic and Pacific tropical and subtropical seas and are a subfamily of venomous elapid snakes (Elapidae) that consists of Hydrophiinae (true sea snakes) and Laticaudinae (sea kraits; Smith 1926, Dunson 1975, Heatwole 1987, Rasmussen 2001). Throughout the world, 62 sea snake species in Hydrophiinae and eight species in Laticaudinae are known (Smith 1926, Heatwole 1987, Slowinski et al. 1997, Rasmussen 2001, 2011b, Scanlon and Lee 2004, Heatwole et al. 2005, Sanders et al. 2013, 2014). In East Asia (i.e., Korea, China, Taiwan, and Japan), a total of 16 sea snake species are listed: 13 in Hydrophiinae and three in Laticaudinae (Won 1971, Kang and Yoon 1975, Mao and Chen 1980, Zhao and Adler 1993, Toriba 1994, Goris and Maeda 2004). The listing of sea snakes in various countries is ongoing. Identifying which species are present is particularly important in understanding the potential distributional changes of sea snakes due

\footnotetext{
* Correspondence: parkda@kangwon.ac.kr

${ }^{5}$ Division of Science Education, Kangwon National University, Chuncheon 200-701, South Korea

Full list of author information is available at the end of the article
}

to global oceanic warming. Reports of undescribed ocean species such as invertebrates and fishes are continuously increasing in Korea and more attention needs to be given to this documentation (Seo and Lee 2009, Song et al. 2010, Jung et al. 2014).

In Korea, only three sea snake species (Hydrophis platurus, $H$. melanocephalus, and $H$. cyanocinctus), all in the Hydrophiinae, have been listed (Stejneger 1907, Shannon 1956, Won 1971, Kang and Yoon 1975) based on anecdotal capture cases and newspaper reports. To date, no one has undertaken a rigorous classification of any sea snake species caught in Korean waters. There are still only two published studies of Korean sea snakes (Lee et al. 2003, Lee et al. 2013). Lee et al. (2003) reported the body size of a slender-necked sea snake (H. melanocephalus), that was accidently caught in a fishing net at the Sooyoung Bay, Sooyoung-gu, Busan-si, on 22 August 1995, but they did not mention any specific morphological characteristics of the species nor classify the species by employing classification keys. In addition, the animal was not preserved nor were any photographs provided in the paper. More recently, Lee et al. (2013) suggested the possibility of both Hydrophiinae 
and Laticaudinae sea snakes inhabiting Korean waters based on photographs taken in Geomun and Jeju Island waters. In 2015, a sea snake previously undescribed in Korea, Laticauda semifasciata, has been caught in Jeju Island waters (unpublished data, submitted for publication).

In the process of thorough examination of the status of Korean sea snakes, we obtained photographs from the first author of the article by Lee et al. (2003) and, surprisingly, found that the slender-necked sea snake had been misidentified. Fortunately the photographs that exist are of high quality. In this study, we re-examined photographs taken during the examination of the snake in 1995 and determined the slender-necked sea snake to be the Chinese sea snake ( $L$. semifasciata). Our result is critical in correcting one of only two reports on sea snakes, previously published in Korea.

\section{Materials and methods}

For the re-identification, we used 13 photographs that were taken during the examination of the sea snake in 1995. Ordinarily, a preserved specimen would be the first choice. But, given the importance of the original report, we were fortunate that there is excellent photographic documentation. We obtained the photographs from the first author of the Lee et al. (2003) article (who is one of the co-authors of this paper). The 13 photographs had sufficient resolution to identify several important classification keys for the sea snake. Based on Mao and Chen (1980), Rasmussen (2001), Goris and Maeda (2004) and Heatwole et al. (2005), we examined the color of the head and body, characteristics of stripes on the body trunk, lateral or dorsal direction of the nostrils, characteristics of ventral scales and rostral scales, and the presence of internasal scales on the head. Then, based on the examination, we were able to correctly determine the identity of the snake.

\section{Results and discussion}

The snake in the photographs had a vertical paddle-like tail (Fig. 1a), enlarged ventral scales (Fig. 1b), internasal scales on the head, and lateral nostrils (Fig. 2b). These characteristics strongly indicate that the snake in the photographs is a sea snake in Laticaudinae and not in Hydrophiinae, as originally reported in Lee et al. (2003). The vertical paddle-like tail has developed in sea snakes to effectively produce propulsive force in water environments (Dunson 1975, Heatwole 1987, Rasmussen et al. 2011a). Since sea snakes in Laticaudinae use both sea and terrestrial habitats, they have evolved enlarged ventral scales for effective ground locomotion. In addition, they have internasal scales on the head, and the direction of their nostrils is lateral (Dunson 1975, Heatwole 1987, Rasmussen 2001). In contrast, sea snakes in Hydrophiinae spend their whole life in the sea and have only rudimentary ventral scales. They do not have internasal scales, and their nostrils are dorsally located (Dunson 1975, Heatwole 1987, Rasmussen 2001).

The color of the head and main body of the snake in the photographs was brown and pale blue (Fig. 1a-c). In particular, dark-brownish cylindrical stripes that encircled the body trunk from the head to the end of the tail showed evident "V"-shaped stripes (Fig. 1c), especially towards the
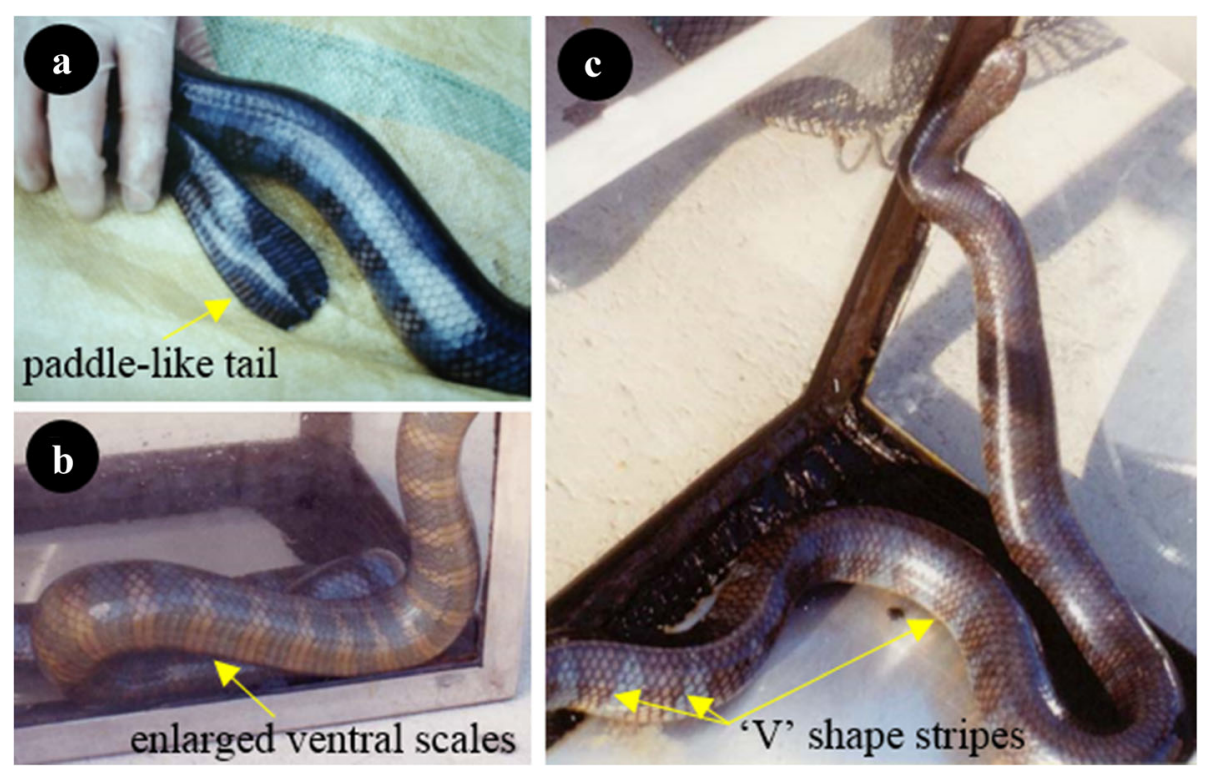

Fig. 1 Photographs of Laticauda semifasciata, caught in 1995 and misidentified as Hydrophis melanocephalus in Lee et al. (2003). Arrows in each photograph indicate an important classification trait for the species: paddle-like tail (a), enlarged ventral scales (b), and "V"-shaped stripes on the body trunk (c) 


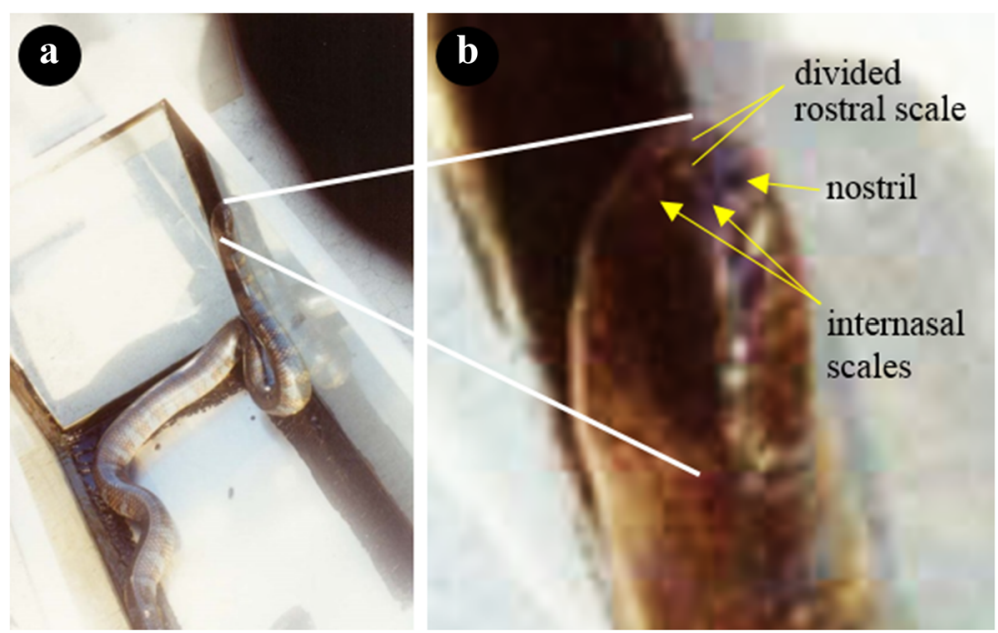

Fig. 2 Presence of divided rostral scale, two internasal scales, and lateral nostrils (b) was confirmed on the head of Laticauda semifasciata (a), which was used in Lee et al. (2003)

end of the tail (Mao and Chen 1980, Goris and Maeda 2004, Rasmussen et al. 2011a). Additionally, the snake in the photographs had a divided rostral scale on the head (Fig. 2b). These characteristics of the snake indicate that it is $L$. semifasciata. Neither of the two other Laticaudinae sea snakes (L. colubrina, L. laticaudata) that previously have been reported to occur in East Asia (Won 1971, Kang and Yoon 1975, Mao and Chen 1980, Zhao and Adler 1993, Toriba 1994, Goris and Maeda 2004) share these characteristics with $L$. semifasciata. L. colubrina and L. laticaudata share characteristics such as narrow black stripes on the body trunk and an unseparated rostral scale on the head (Mao and Chen 1980, Rasmussen et al. 2011a) further distinguishing them from $L$. semifasciata.

Our results show that the sea snake caught in 1995 was L. semifasciata and the record is the first capture case of the species in Korean waters. Our result in itself behooves us to correct the prior report of Lee et al. (2003) and properly identify the snake that they reported as $H$. melanocephalus. This is particularly important in light of the IUCN listing of $L$. semifasciata as near threatened with estimates of it having declined by over $90 \%$ since 1974 due to over harvest (Lane and Gatus 2010). The fishery collapsed in the Philippines at that time but is still ongoing in Japan. Therefore, it is estimated that declines are still occurring and they call for more research on abundance and population status, as this species may qualify for a threatened category, especially given its shallow-water habitat and current rarity (Lane and Gatus 2010). In addition, Korean occurrence of the species suggests a northern range extension for the species that ties in with observations of increased ocean temperatures in Korean waters (Jung 2008, Jung et al. 2014).

In conclusion, our results show that the snake in the photographs that were taken in 1995 and had been reported as
H. melanocephalus in Lee et al. (2003) should be correctly identified as $L$. semifasciata. Therefore, the snake caught 30 years ago should be considered as the first capture case of a Laticaudinae sea snake species in Korean waters. Our ongoing research suggests that there might be more unrecorded sea snake species in Korea, and given the data deficiency for these species, studies related to the conservation of this group in light of over fishing and oceanic temperature change is becoming increasingly imperative.

\section{Additional file}

Additional file 1: Sea snake photographs used in the study. (DOCX $621 \mathrm{~kb}$ )

\section{Acknowledgements}

We thank T. Tokuda and M. Toda for their help in confirming the misidentified sea snake species and C. Marshall of Oregon State University for discussion.

\section{Funding}

This research was supported by Basic Science Research Program through the National Research Foundation of Korea (NRF) funded by the Ministry of Education (2014R1A1A4A01005302).

\section{Availability of data and materials}

All data generated or analyzed during this study are included in this published article [and its Additional file 1].

\section{Authors' contributions}

IHK and DP conceived and designed the experiments. JP and DP analyzed the data. IHK, JP, RHK, and DP wrote the manuscript. JNL and IHK are responsible for the data collections. All authors read and approved the final manuscript.

Competing interests

The authors declare that they have no competing interests.

Consent for publication

Not applicable.

Ethics approval and consent to participate Not applicable. 


\section{Author details}

'Department of Biology, Kangwon National University, Chuncheon 200-701, South Korea. ${ }^{2}$ Marine Biodiversity Institute of Korea, Seocheon 325-902, South Korea. ${ }^{3}$ Department of Biology, Reed College, Portland, OR 97202, USA.

${ }^{4}$ Department of Biology, Kyungsung University, Busan 608-736, South Korea. ${ }^{5}$ Division of Science Education, Kangwon National University, Chuncheon 200-701, South Korea.

Received: 22 December 2015 Accepted: 24 June 2016

Published online: 24 October 2016

\section{References}

Dunson, WA (1975). The biology of sea snake. Baltimore: University Park Press.

Goris, RC, \& Maeda, N (2004). Guide to the amphibians and reptiles of Japan. Malabar: Krieger Publishing Company.

Heatwole, H (1987). Sea snakes. Kensington: University of New South Wales Press. Heatwole, H, Busack, S, \& Cogger, HG (2005). Geographic variation in sea kraits of the Laticauda colubrina complex (Serpentes: Elapidae: Hydrophiinae: Laticaudini). Herpetol Monog, 19, 1-136.

Jung, S (2008). Spatial variability in long-term changes of climate and oceanographic conditions in Korea. Journal of Environmental Biology, 29, 519-529.

Jung, S, Pang, IC, Lee, JH, Choi, I, \& Cha, HK (2014). Latitudinal shifts in the distribution of exploited fishes in Korean waters during the last 30 years: a consequence of climate change. Rev Fish Biol Fisher, 24, 443-462.

Kang, YS, \& Yoon, IB (1975). Illustrated encyclopedia of fauna and flora of Korea. Vol. 17. Amphibia and reptilia. Seoul: Sam Hwa Press.

Lane A, Gatus J. Laticauda semifasciata. In: The IUCN red list of threatened species. 2010. http://dx.doi.org/10.2305/IUCN.UK.2010-4.RLTS.T176721A7290432.en. Accessed 27 July 2015

Lee, JN, Kang, SH, Moon, SG, \& Lee, IS (2003). On the reptiles of 8 species collected in Busan area-Caretta caretta, Clemmys japonica, Trachemys scripta elegans, Gekko japonicus, Eremias argus, Elaphe schrenckii, Dinodon rufozonatum, Hydrophis melanocephalus. Bull Basic Sci Res Cent Kyungsung Univ, 15, 153-160.

Lee, HJ, Kim, IH, \& Park, D (2013). Telephone inquiry and local interview on the observation of Korean sea snakes. Korean I Herpetol, 5, 45-52.

Mao, SH, \& Chen, BY (1980). Sea snakes of Taiwan: a natural history of sea snakes. Taipei: National Science Council.

Rasmussen, AR (2001). Sea snakes. In K. E. Carpenter \& V. H. Niem (Eds.), FAO species identification quide for fishery purposes. The living marine resources of the Western Central Pacific (Body fishes Part 4 (Labridae to Latimeriidae), estuarine crocodiles, sea turtles, sea snakes and marine mammals, Vol. 6, pp. 3987-4008). Rome: FAO

Rasmussen AR, Elmberg J, Gravlund P, Ineich I. (2011a). Sea snakes (Serpentes subfamilies Hydrophiinae and Laticaudinae) in Vietnam: a comprehensive checklist and an updated identification key. Zootaxa, 2894:1-20.

Rasmussen AR, Murphy JC, Ompi M, Gibbons JW, Uetz P. Marine reptiles. PloS One. 2011 b. doi:10.1371/journal.pone.0027373.

Sanders, KL, Lee, MSY, Bertozzi, T, \& Rasmussen, AR (2013). Multilocus phylogeny and recent rapid radiation of the viviparous sea snakes (Elapidae: Hydrophiinae). Molecular Phylogenetics and Evolution, 66, 575-591.

Sanders, KL, Rasmussen, AR, \& Guinea, ML (2014). High rates of hybridization reveal fragile reproductive barriers between endangered Australian sea snakes. Biological Conservation, 171, 200-208.

Scanlon, JD, \& Lee, MSY (2004). Phylogeny of Australasian venomous snakes (Colubroidea, Elapidae, Hydrophiinae) based on phenotypic and molecular evidence. Zoologica Scripta, 33, 335-366.

Seo KS, Lee Y. A first assessment of invasive marine species on Chinese and Korean coasts. In: Rilov G, Crooks JA, editor. Biological invasions in marine ecosystems: ecological studies (Vol. 204). Berlin Heidelberg: Springer-Verlag; 2009. p. 577-85.

Shannon, FA (1956). The reptiles and amphibians of Korea. Herpetologica, 12, 22-49.

Slowinski, J. B., Knight, A., \& Rooney, A. P. (1997). Inferring species trees from gene trees: a phylogenetic analysis of the Elapidae (Serpentes) based on the amino acid sequences of venom proteins. Molecular Phylogenetics and Evolution, 8, 349-362

Smith, MA (1926). Monograph of the sea snakes (Hydrophiidae). London: Oxford University Press.

Song, SJ, Kim, W, \& Hwang, UW (2010). First record of the family Cletopsyllidae (Copepoda: Harpacticoida) from Korean waters, with description of a new species. Anim Cell Syst, 14, 351-360.
Stejneger, L (1907). Herpetology of Japan and adjacent territory (Washington Government Printing Office: United States National Museum Bulletin, Vol. 58, pp. 313-315)

Toriba, M (1994). Sea snakes of Japan. In P. Gopalakrishnakone (Ed.), Sea snake toxinology (pp. 206-211). Singapore: Singapore University Press.

Won, HG (1971). Amphibian and reptiles of Chosun. Pyeongyang: Pyeongyang Printing Office.

Zhao, EM, \& Adler, K (1993). Herpetology of China. Oxford: Society for the Study of Amphibians and Reptiles.

\section{Submit your next manuscript to BioMed Central and we will help you at every step:}

- We accept pre-submission inquiries

- Our selector tool helps you to find the most relevant journal

- We provide round the clock customer support

- Convenient online submission

- Thorough peer review

- Inclusion in PubMed and all major indexing services

- Maximum visibility for your research

Submit your manuscript at www.biomedcentral.com/submit
C Biomed Central 